\title{
Rainfall characteristics for periglacial debris flows in the Swiss Alps: past incidences-potential future evolutions
}

\author{
Markus Stoffel • Michelle Bollschweiler • \\ Martin Beniston
}

Received: 22 November 2009 / Accepted: 14 January 2011 / Published online: 8 February 2011

(C) Springer Science+Business Media B.V. 2011

\begin{abstract}
Based on observational meteorological data since A.D. 1864 and tree-ring records of debris-flow activity, this paper assesses changes in rainfall characteristics and their impact on the triggering of geomorphic events in a high-elevation watershed of the Swiss Alps since the end of the Little Ice Age. No trends are visible in the frequency of heavy rainfall events, but we observe a reduced number of heavy, shortlived rainfalls in summer and a concentration of advective storms is recorded in late summer and early fall since the late 1980s. These changes in triggering meteorological conditions resulted in a cluster of debris flows in the early decades of the twentieth century and a lowering of debris-flow activity since the mid 1990s, and may be mirroring the observed changes in persistent high-pressure systems over the Alps. We also observe intra-seasonal differences in debris-flow system response reflecting the state of the permafrost body in the source area of debris flows, allowing for very small debris flows to be released by limited rainfall inputs $(<20 \mathrm{~mm})$ in June and July. The same quantities of rain will not trigger debris flows in August or September, when a thick active layer of the permafrost body is capable of absorbing water. With the projected amplitude of climatic change, seasonality, return intervals and volumes of debris flows are likely to be altered. RCM projections based on the IPCC A2 scenario suggest a decrease in heavy summer rainfalls which will most likely result in a (further) reduction of the overall frequency of debris flows, leaving more time for sediment to accumulate in the channel. Such an increase of channel accumulation rates along with the projected destabilization of the steep rock-glacier body is likely,
\end{abstract}

M. Stoffel $(\varangle) \cdot$ M. Bollschweiler · M. Beniston

Climatic Change and Climate Impacts Group (C3i), Institute for Environmental Sciences,

University of Geneva, Chemin de Drize 7, 1227 Carouge-Geneva, Switzerland

e-mail: markus.stoffel@dendrolab.ch

M. Stoffel · M. Bollschweiler

Laboratory of Dendrogeomorphology (dendrolab.ch), Institute of Geological Sciences,

University of Bern, Baltzerstrasse 1+3, 3012 Bern, Switzerland 
in turn, to exert control ultimately on sediment volumes released from the source areas during future events. Observations from adjacent catchments suggest that extremely large debris flows, beyond historical experience, could occur at the study site and in similar debris-flow systems of the Valais Alps originating from periglacial environments.

\section{Introduction}

Debris flows represent one of the most common geomorphic processes in many mountain regions, such as the Swiss Alps, where their occurrence repeatedly causes severe damage to communication routes, infrastructure or even loss of life (Bollschweiler et al. 2008a, b; Stoffel et al. 2008a; Bollschweiler and Stoffel 2010a, b). With the projected greenhouse effect and global warming (IPCC 2007), changing climatic conditions are expected to favor the occurrence of extreme climatic events (e.g., Tebaldi et al. 2006; Beniston 2007) that in turn will enhance a wide range of impacts on the hydrologic cycle (Allen and Ingram 2002; Wentz et al. 2007) in general and fluvial systems (Goudie 2006) in particular. On a global level, Milly et al. (2002) state that the frequency of great floods had increased substantially in large river basins during the twentieth century. For the Swiss Alps, projections based on observational data and RCM output (IPCC A2 scenario) suggest extreme rainfalls to occur less often in summer by 2100 but more frequently in spring and fall, when the buffering effects of snowfall at high elevations may either limit runoff in Alpine catchments or-in the case of spring-time events at temperatures above the freezing level-trigger early snow melt and thus additional critical water amounts (Beniston 2006).

Rainfall intensity and duration also drive and control mass-movement processes such as landslides or debris flows (Evans and Clague 1994). Rainfall thresholds resulting in slope failure and debris-flow activity have been addressed for many mountain regions of the world (Crozier 1999; Godt et al. 2006; Guzzetti et al. 2008) and were mostly determined via a combination of rainstorm intensity with rainstorm duration (Caine 1980).

Similarly, the impacts of contemporary and predicted future changes in rainfall activity (Schmidli and Frei 2005) on the initiation of debris flows have been reported by different case studies: While Rebetez et al. (1997) suggest that debris-flow activity would increase in a future greenhouse climate in the Swiss Alps, Jomelli et al. (2004, 2007, 2009), in contrast, demonstrate that events would be released less often in the Massif des Ecrins (France) by 2100. As observational data on precipitation and records on former debris-flow activity do not normally cover more than a few decades, previous work was mostly limited to the analysis of very recent events and to contemporary trends of process activity.

This paper assesses rainfall characteristics capable of triggering debris flows in a high-elevation watershed of the Swiss Alps since the end of the Little Ice Age (LIA; Grove 2004) in the middle of the nineteenth century. Through the comparison of a unique, highly resolved tree-ring record of debris flows with daily precipitation data since A.D. 1864, we focus on (1) the assessment of long-term changes of temperature, precipitation, and pressure systems at the study site, (2) a determination of debrisflow triggering rainfall events and their changes in time, (3) shifts in the seasonality 
of heavy rainfalls and their impact on debris-flow activity, and on (4) the potential future evolution of mass-wasting events in this high-elevation catchment of the Valais Alps (Switzerland).

\section{Study site}

The case-study area chosen for analysis of triggering precipitation thresholds of past and present-day debris flows is the Ritigraben, a small high-elevation watershed of the Valais Alps (Switzerland, 46 $11^{\prime}$ N, $7^{\circ} 49^{\prime}$ E; Fig. 1). In the source area of the torrent located at 2,600 $\mathrm{m}$ a.s.l., geophysical and borehole prospecting indicate the existence of contemporary permafrost (Lugon and Stoffel 2010). Previous investigations on the intermediate cone (32 ha) focused on the reconstruction of past debrisflow events. Dendrogeomorphic analysis of 1,204 disturbed trees (2,450 cores) as well as the analysis of archival data allowed reconstruction and documentation of 124 events for the period 1570-2008 (Stoffel et al. 2008b). For the last 300 year (i.e. 17062005), results suggest a mean annual frequency of 0.33 events (Stoffel and Beniston 2006; Stoffel 2010).

The study site is located in a dry inner-alpine valley, with debris flows occurring primarily as a result of localized convective (thunderstorms) or regional advective (persistent rainfall) storm events. Generally, convective storms are most commonly observed in summer, advective storms tend to be more frequent in late summer and fall, when strong low pressure systems located in the Mediterranean Sea (socalled Genoa lows) adduct wet-warm air masses toward the Alps over several days (Grebner and Roesch 1998). As a result of the high elevation of the source area, present-day debris-flow activity is restricted from June to September. Comparison of
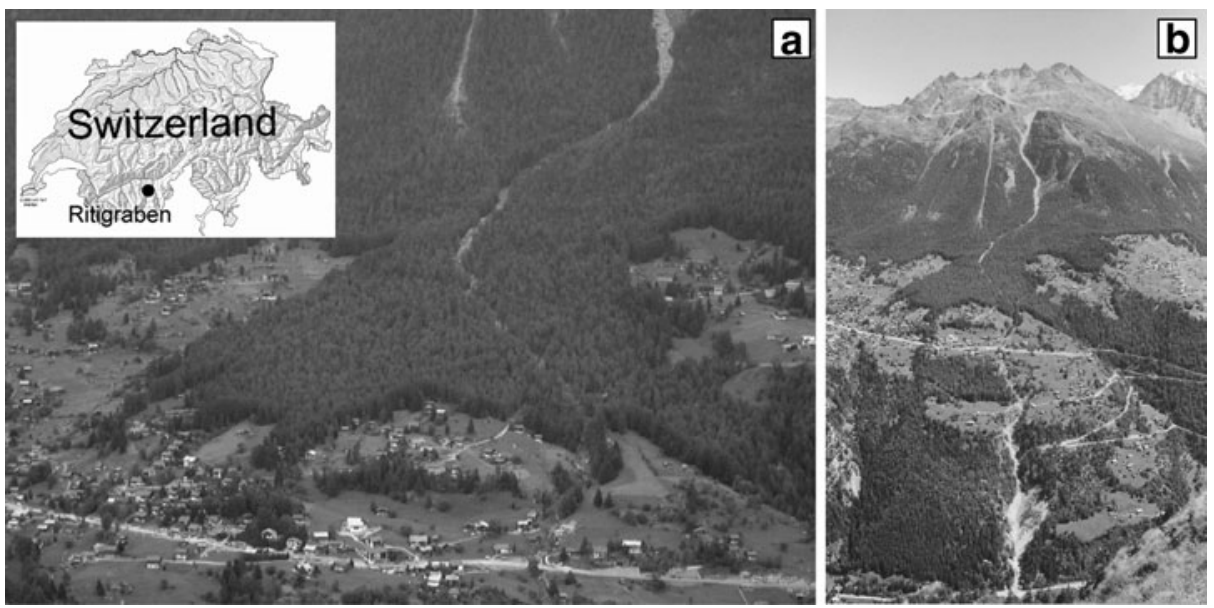

Fig. 1 The Ritigraben torrent (Valais, Swiss Alps) rises from its source at 2,600 m a.s.l. and passes through a forested cone located on a structural terrace near the village of Grächen before converging with the Mattervispa River (1,080 m a.s.l.): a detail of the intermediate debris-flow cone (32 ha) and its mixed conifer stand. b View of the debris-flow system (catchment area: $1.36 \mathrm{~km}^{2}$, channel length: $3.5 \mathrm{~km})$ 
reconstructed debris-flow occurrences with archival records on flooding in neighboring rivers (Stoffel et al. 2005a; Bollschweiler and Stoffel 2010a) show a clear peak in activity in July and August (32\% each) for the entire period of the reconstruction (1570-2008). In contrast, if only the last 50 years are taken into account, activity is largest in August and September, with almost a complete absence of mass movements in June and July (Stoffel and Beniston 2006).

The frequency-magnitude $(\mathrm{F}-\mathrm{M})$ relationship for debris flows at Ritigraben is based on tree-ring and geomorphic data and covers the last $150 \mathrm{yr}$ (Stoffel 2010). Data indicate that the typical size-range of debris flows encompasses $S$ - and $M$-sized events $\left(<5 \times 10^{3} \mathrm{~m}^{3}\right)$ and exceptional $X L$ incidences (1922, 1948, and 1993; $<5 \times$ $10^{3} \mathrm{~m}^{4}$ ). Debris-flow magnitude has been systematically recorded for the last $15 \mathrm{yr}$, with volumes transported varying from $3-5,000 \mathrm{~m}^{3}(1994,2002,2008)$ to an estimated $60,000 \mathrm{~m}^{3}$ in 1993 (Zimmermann et al. 1997).

\section{Material and methods}

\subsection{Changes in temperature, precipitation, and weather patterns}

The Swiss Federal Office of Meteorology and Climatology (MeteoSwiss 2009) maintains a dense network of observation stations and also operates a recording station in Grächen ( $46^{\circ} 11^{\prime} \mathrm{N}, 7^{\circ} 49^{\prime} \mathrm{E} ; 1,619 \mathrm{~m}$ a.s.l.). The station is located $\sim 1.3 \mathrm{~km}$ north of the Ritigraben torrent and has been operational almost continuously since A.D. 1864. Records (i.e. non-homogenized data) include 24-h precipitation sums, minimum, maximum and mean temperatures as well as snow depths.

We assessed trends and changes in daily maximum temperatures $\left(T_{\max }\right)$ and precipitation (simple linear regressions and $Q_{95}$ ). One manner of summarizing the possible combined effects of temperature and precipitation as the most obvious trigger mechanism for debris flows is to analyze statistics of joint probability density functions (PDF), as discussed by Beniston and Goyette (2007) and applied to extreme events in Switzerland by Beniston $(2007,2009)$. The method is fairly simple but has the merit in that it exhibits a certain degree of objectivity. The computation of joint tails of PDFs of two climate variables $V 1$ and $V 2$ involves computing of the simultaneous exceedances of $V 1$ and $V 2$ for combinations of the $\mathrm{Q}_{5}$ and $\mathrm{Q}_{95}$, i.e., $V 1_{5} / V 2_{5}, V 1_{95} / V 2_{5}, V 1_{5} / V 2_{95}$, and $V 1_{95} / V 2_{95}$; subscripts 5 and 95 refer to the respective quantile level for variable $V 1$ and $V 2$. Frequencies are computed by counting the number of occurrences above or below a particular quantile threshold for each season, using the 1961-1990 reference period to determine the quantile levels used.

A complementary method to investigate the evolution of weather patterns is through the change in the behavior of high- or low-pressure systems in the Alps. Pressure is not recorded at Grächen, but since this variable represents an aspect of the dynamic state of the atmosphere at a larger spatial scale than that of the local site considered, using pressure data from another station is not a problem for long-term statistical analyses. Daily pressure data from Davos has thus been used; it is located in the eastern Swiss Alps (46 48 $\mathrm{N}, 9^{\circ} 49^{\prime} \mathrm{E} ; 1,570 \mathrm{~m}$ a.s.l.) at an equivalent altitude to Grächen. 


\subsection{Dendrogeomorphic reconstruction of past debris flows}

The reconstruction of past debris flows was performed with dendrogeomorphology (Alestalo 1971; Stoffel et al. 2010), a technique identifying and dating growth anomalies in trees inflicted by debris-flow impacts. On the cone of the Ritigraben torrent, a vast majority of the century-old European larch (Larix decidua Mill.), Norway spruce (Picea abies (L.) Karst.) and Swiss stone pine (Pinus cembra L.) trees exhibits visible defects in their morphology (e.g., tilted stems, partial trunk burial, destruction or erosion of the root mass, or scars). At least two increment cores were extracted from each of the disturbed trees. In addition to the disturbed trees, we selected undisturbed reference trees from a forest stand located next to the cone. In total, 1,204 trees were sampled (2,450 increment cores): 539 L. decidua, $429 P$. abies and $134 P$. cembra trees (2,246 cores) from the debris-flow cone as well as 102 undisturbed trees (204 cores) from the reference site.

In the laboratory, tree samples were analyzed and data processed following the standard procedures described in Stoffel and Bollschweiler (2008, 2009). Growth curves of the disturbed samples were cross-dated with the reference chronology to separate insect attacks or climatically driven fluctuations in tree growth from disturbances caused by debris flows (Cook and Kairiukstis 1990). Error-corrected increment curves from the disturbed trees were then used to determine the onset of abrupt growth reduction or recovery (McAuliffe et al. 2006; Mayer et al. 2010). In the case of tilted stems, both the appearance of cells (i.e. geometry of the reaction wood cells) and the growth curve data were analyzed (Braam et al. 1987; Fantucci and Sorriso-Valvo 1999). Cores were also visually inspected to identify further signs of past debris-flow activity. For instance, the corrasion of stems causes cambium damage (cambium $=$ wood-producing tissue of trees) and results in the formation of callus tissue overgrowing these scars (Hupp 1984). Another typical feature in injured L. decidua and $P$. abies are tangential rows of traumatic resin ducts (TRD; Stoffel 2008), formed as a means of protection against insect and pathogen attacks following cambium damage (e.g., Bollschweiler et al. 2008b; Stoffel and Hitz 2008; Schneuwly et al. 2009a, b). As trees react immediately to damage with the formation of callus tissue and TRD, the intra-annual position of disturbance (i.e. early, mid and late earlywood or early and late latewood; for details see Stoffel et al. 2005b, 2006) was used to reconstruct the timing of debris-flow activity in particular years. For the Valais Alps, highly resolved data exist on the radial growth of L. decidua and $P$. abies, rendering dating of past debris-flow events at Ritigraben possible with monthly precision (Stoffel et al. 2008b and references therein). Results obtained on the intra-seasonal timing of debris flows were also compared with meteorological and hydrological data as well as archival records on flooding in rivers of the wider study region (Lütschg-Lötscher 1926; Röthlisberger 1991; Bollschweiler and Stoffel 2010a) to further improve dating accuracy.

\subsection{Coupling tree-ring records with meteorological data}

In a last analytical step, we compared monthly resolved tree-ring data on debrisflow events with non-homogenized meteorological data so as to identify (1) precipitation events and associated rainfall totals recorded during the occurrence of past 
mass-wasting events, (2) the role of antecedent rain or snowmelt ("rain-on-snow" events), and (3) storm type (advective or convective) leading to the release of debris flows at Ritigraben, before (4) the role of meteorology on debris-flow magnitude (see Stoffel 2010 for details on event-size reconstruction) and (5) the implications that climatic change might have on the occurrence of debris flows are discussed for this small catchment in the Swiss Alps in particular and the wider Alpine region in general.

\section{Results}

\subsection{Changes of temperature and precipitation}

Temperature trends at Ritigraben, based on the data sets of the nearby climatic observing station of Grächen, exhibit strong warming tendencies, both annually (not shown) and for the two seasons which currently experience debris-flow events, namely summer (June, July, and August, or JJA) and fall (September, October, and November, or SON), as given in Fig. 2. Simple linear regression shows that summertime $T_{\max }$ has increased at a rate of $3.3^{\circ} \mathrm{C}$ per century, and falls by over $2.5^{\circ} \mathrm{C}$ per century. This can be considered a significant rate of change since temperatures have exceeded the upper bound of the $95 \%$ range of temperature variability of the twentieth century record since the early 1990 s (i.e., a range from $14.5-20.1^{\circ} \mathrm{C}$ for JJA and $6.4-12.0^{\circ}$ for SON). Also shown in Fig. 2 are $\mathrm{Q}_{95}$ of $T_{\max }$ for the two selected seasons, that exhibit essentially the same behavior but with a shift towards warmer values with respect to seasonal means by $6-7^{\circ} \mathrm{C}$. The persistence of particularly warm events has also risen quite sharply over the past two decades. In summer, the exceedance of days beyond $25^{\circ} \mathrm{C}$ has increased from less than an average of 2 days per season in the period prior to 1980 to over 11 days per season since; similarly for

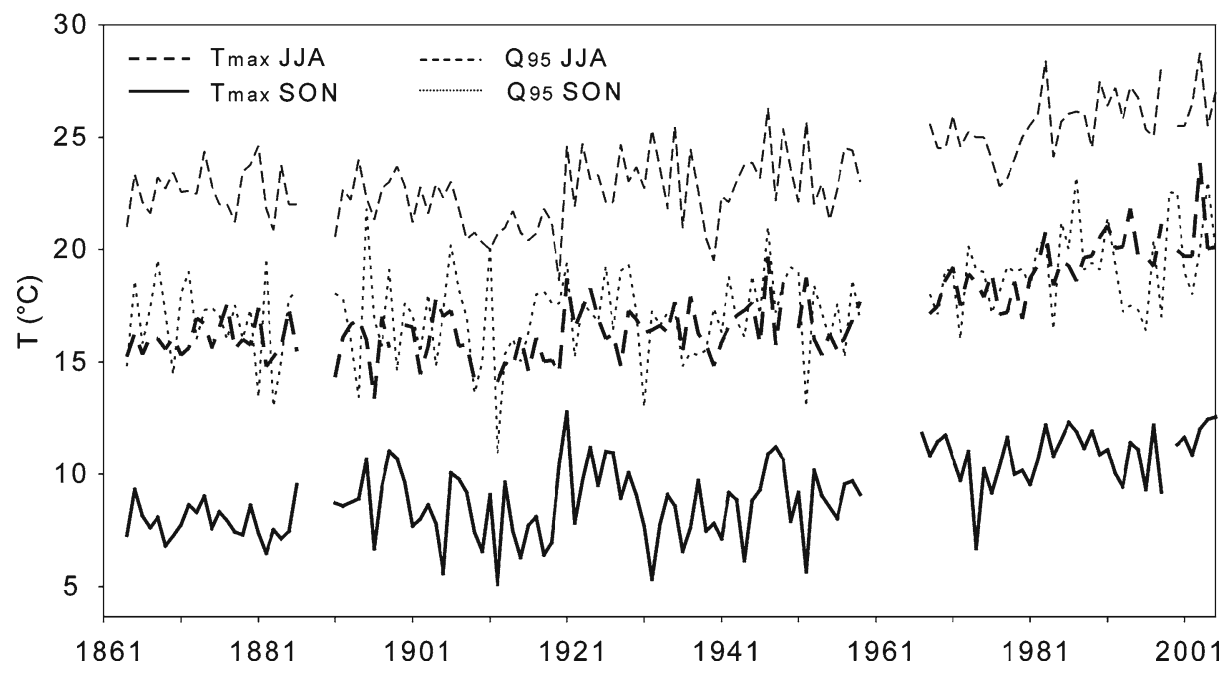

Fig. 2 Changes in summer (JJA) and fall (SON) temperatures since A.D. 1864, illustrated with maximum temperatures $\left(T_{\max }\right)$ and the $95 \%$ quantiles of $T_{\max }$ for the two selected seasons 
fall, the exceedance of the $20^{\circ} \mathrm{C}$ threshold has doubled over the same period, from 14 to 28 days per season.

Because late summer and fall are the most likely times of the year for debris-flow activity at Ritigraben, we shall briefly analyze here the behavior of another essential

Fig. 3 Maximum cumulative precipitation amounts for 24 , 72 and 120 h (i.e. 1, 3 and 5 consecutive days) of rainfall in fall
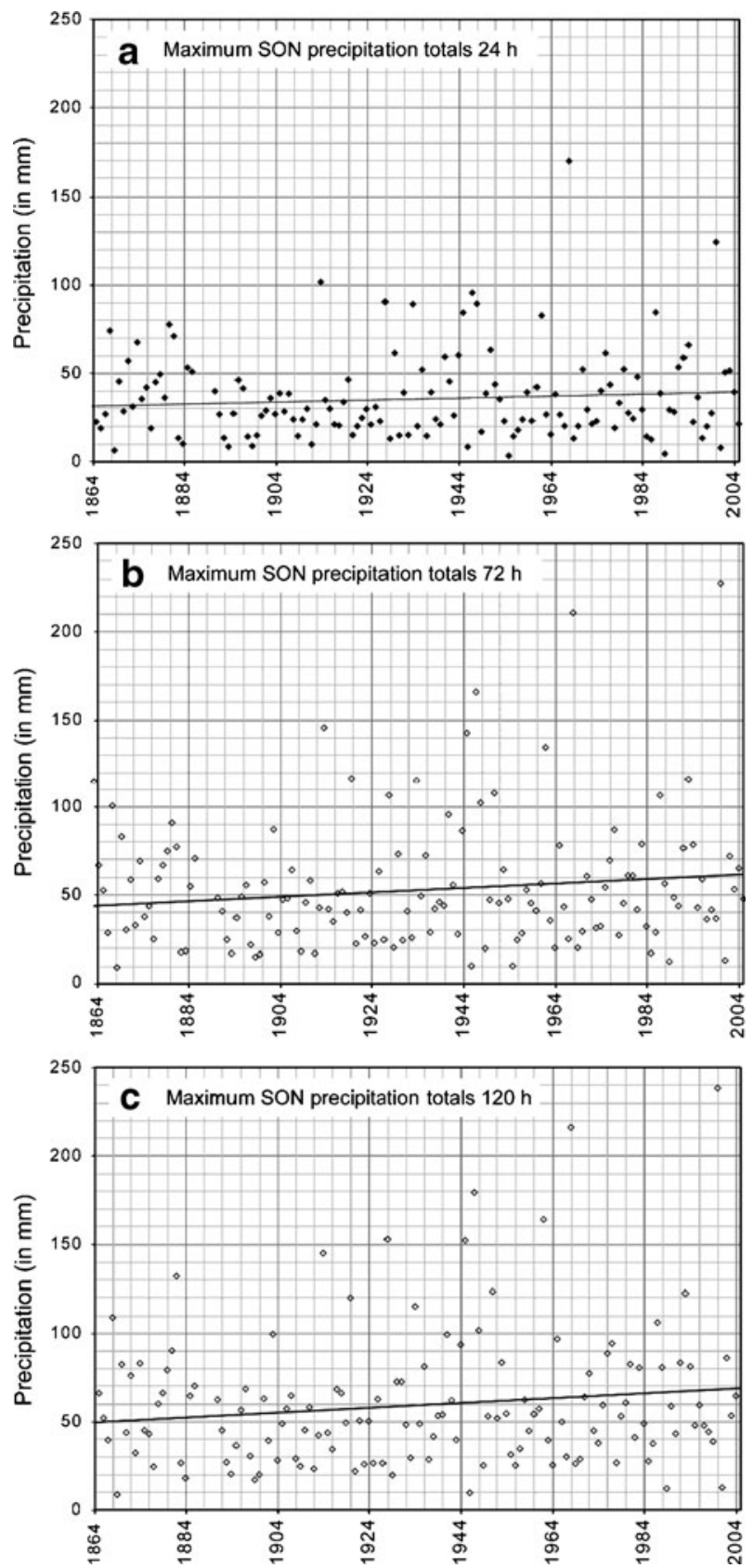
climate driver of mass-wasting activity, i.e., precipitation. Mean and maximum fall (SON) precipitation shows no trend over the period $\left(\mathrm{r}^{2}=0.02\right.$ and 0.008 , respectively), and exhibits a very high level of inter-annual variability. It is thus important to distinguish between abrupt, short-lived heavy precipitation events, and continuous rainfall over one or several days that can ultimately supply the critical amounts of water needed to trigger what may mature into a full debris-flow event. Figure 3 shows the course of cumulative precipitation amounts for 1, 3 and 5 consecutive days of rainfall in fall. Events exceeding $50 \mathrm{~mm} \mathrm{day}^{-1}$ (corresponding roughly to the $99 \%$ quantile of precipitation) occur roughly 1 year in four (Fig. 3a), and this trend has not changed in the recent part of the record. The amount of precipitation associated with a heavy precipitation event can of course change, as clearly seen for the high peaks of $1968(170 \mathrm{~mm})$ and $2000(125 \mathrm{~mm})$, for example. However, as we move into the cumulative precipitation of 5 consecutive days, the picture changes somewhat and it is seen that there is an increase in the total cumulative water amounts as we enter into the latter part of the record. The 72-h and 120-h totals (Fig. 3b and c, respectively) do show an increase over time, and even if the change is small it is statistically significant at the $95 \%$ level. The amount of water released over 5 days during major events is seen to have risen from, for example, $145 \mathrm{~mm}$ in 1914, $152 \mathrm{~mm}$ in 1928, $179 \mathrm{~mm}$ in 1947, $216 \mathrm{~mm}$ in 1968, to a record $238 \mathrm{~mm}$ in 2000.

One manner of summarizing the possible combined effects of temperature and precipitation as the most obvious triggering mechanisms for debris flows is to analyze the statistics of joint probability distributions. Figure 4 illustrates the changes

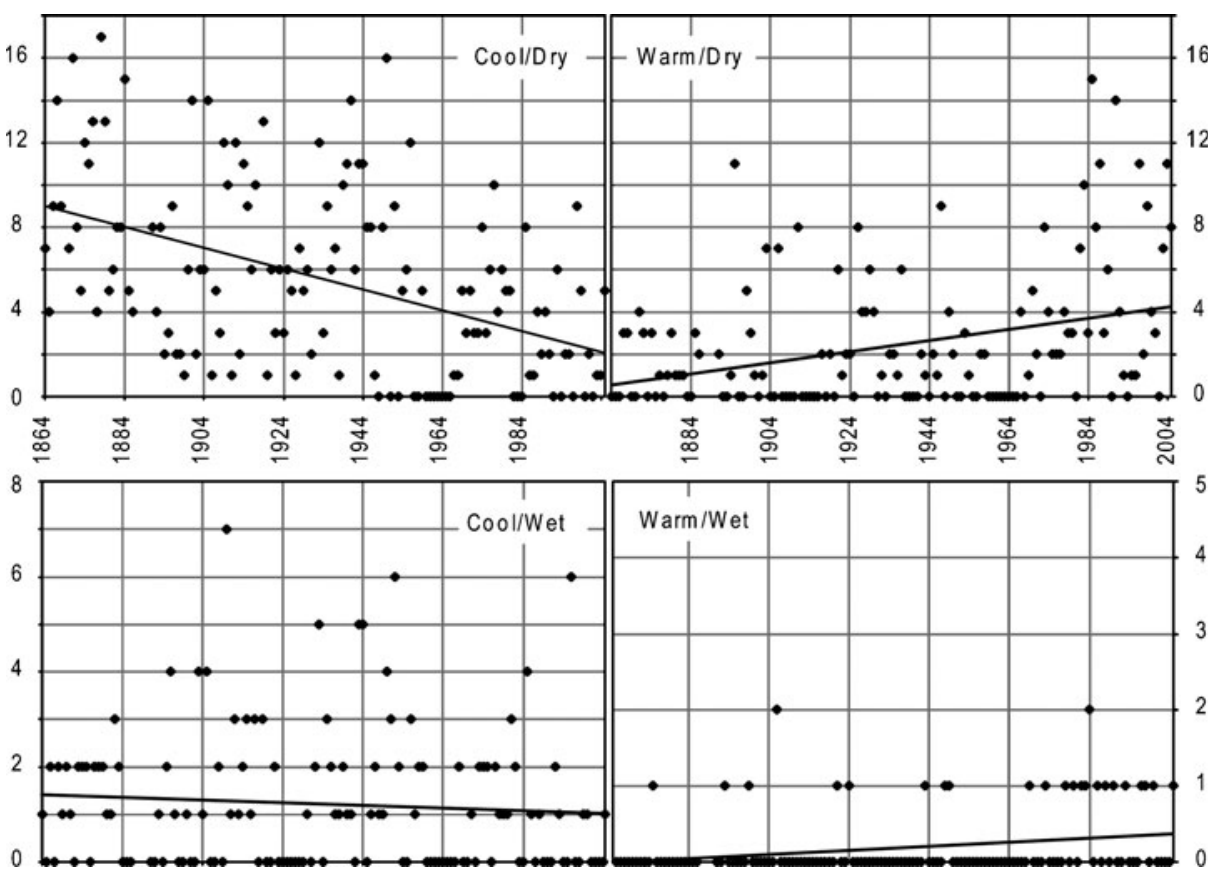

Fig. 4 Changes of joint quantiles of $T_{\max }$ and precipitation for fall between 1864 and 2005 
between 1864 and 2005 of the joint quantiles of $T_{\max }$ and precipitation for fall. The four frames of the figure emphasize the fact that two modes of combined heat and moisture have changed substantially, especially since the early 1970 s, while two other modes do not change to any significant extent. In the first case, the cool-dry mode shows a decrease by a factor of two towards the end of the record, while the warm-dry mode shows a threefold increase of occurrence in the same time frame. The cool-wet mode does not show any long-term change and is characterized by average occurrences of 2-3 times per season with, occasionally, higher exceedances on individual years such as 1910, 1952 or, most recently, 1996. Finally, the warmwet mode is seen to cluster since the end of the 1960s, and is much more sparsely represented in the prior decades, but generally occurs only once per season.

\subsection{Low- and high-pressure occurrences}

The frequency of exceedance of low- and high-pressure occurrences, computed as the exceedances below the $10 \%$ and $90 \%$ quantile thresholds of pressure, shows that low-pressure counts diminish from about 14 events per fall in the 1960 s, to 4 currently (Fig. 5). In the same time frame, a reverse trend is seen to occur for the high-pressure events, from about 5 per fall to over 10 currently. In other words, the cyclonicity of weather events is reduced by almost half over the past 40 years while high pressure events increase by a factor of two during the same time period. Both modes of extreme pressure and their persistence are related to specific types of weather events, i.e., heavy precipitation on the one hand or persistent drought on the other.

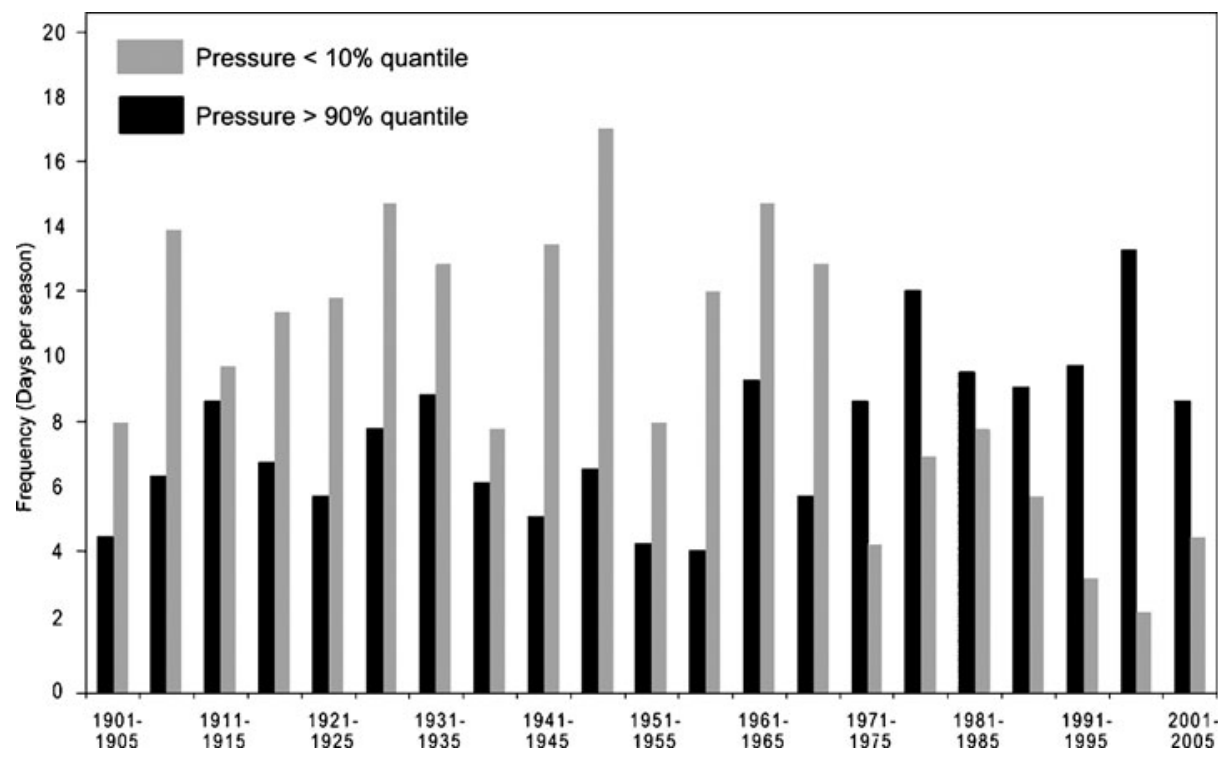

Fig. 5 Frequency of exceedance of low- and high-pressure occurrences per fall, computed as the exceedances below the $10 \%$ and $90 \%$ quantile thresholds of pressure 


\subsection{Rainfall and debris-flow events: past incidences}

In an attempt to foster understanding about how rainfall input is related to debrisflow initiation, we compare reconstructed data on debris-flow frequency and magnitude with precipitation records of the MeteoSwiss station at Grächen since A.D. 1864.

Precipitation totals recorded at the meteorological station during debris-flow events greatly differ and range from 10 to $179 \mathrm{~mm}$ (mean: $40.1 \mathrm{~mm}$; SD: $29.8 \mathrm{~mm}$; see Table 1). As the recording station is located $1.3 \mathrm{~km}$ north and $\sim 950 \mathrm{~m}$ below the release area of debris flows, it is possible that differences exist between rainfall totals at the station and the starting zone of debris flows, Nevertheless, data clearly shows that small precipitation totals would trigger preferentially smaller debris flows $\left(<10^{3} \mathrm{~m}^{3}\right)$ and that extensive rainfalls with large precipitation sums are needed to generate large debris flows at Ritigraben. A comparison of tree-ring with meteorological data also indicates that small- and medium-sized (i.e. $10^{3}-5 \times 10^{3} \mathrm{~m}^{3}$ ) flows are exclusively triggered by convective storms and primarily occur in July and August with associated rainfall totals ranging from 10-52 mm (mean: $27 \mathrm{~mm}$ ). Large events (i.e. $5 \times 10^{3}-10^{4} \mathrm{~m}^{3}$ ) may take place throughout the debris-flow season at Ritigraben (i.e. June through September) but are most common in August. These debris flows are triggered by heavy convective or long-lasting advective storms in late summer and early fall. Precipitation totals for this size-class of debris flows range from 21 to $179 \mathrm{~mm}$ (mean: $51 \mathrm{~mm}$ ). Extensive advective rainfalls over 48-72 $\mathrm{h}$ with precipitation totals averaging $88 \mathrm{~mm}$ were responsible for the three very large (i.e. $10^{4}-5 \times 10^{4} \mathrm{~m}^{3}$ ) debris-flow incidences on 30 August 1922, 5 September 1948 and 24 September 1993. This size-class of debris flows can therefore is exceptional for the site under current climatic conditions.

A vast majority of debris flows at Ritigraben are triggered by convective storms (50 events, $82 \%$ ), advective rainfall events were, in contrast, only responsible for $18 \%$ (11 events) of the debris flows on record. In one out of ten events, we observe antecedent rainfall exceeding $\mathrm{Q}_{90}=66 \mathrm{~mm}$ in the 30 days prior to the event (mean antecedent precipitation totals: $40.58 \pm 42.19 \mathrm{~mm} 30$ day $^{-1}$; max: $95 \mathrm{~mm}$, min: $0 \mathrm{~mm}$ ). Based on the reconstructed intra-seasonal timing of debris-flow events and elevationcorrected $T$ data, nine cases $(15 \%)$ are identified where rain-on-snow combinations presumably facilitated the release of debris flows.

Table 1 Hydrometeorological conditions observed during debris-flow events at Ritigraben since A.D. 1864

\begin{tabular}{lllll}
\hline Characteristics & S & M & L & XL \\
\hline Precipitation type & Convective & Convective & Adv./Conv. & Advective \\
Precipitation totals (mean) & $26 \mathrm{~mm}$ & $27 \mathrm{~mm}$ & $51 \mathrm{~mm}$ & $88 \mathrm{~mm}$ \\
Precipitation totals (min) & $10 \mathrm{~mm}$ & $12 \mathrm{~mm}$ & $21 \mathrm{~mm}$ & $49 \mathrm{~mm}$ \\
Precipitation totals (max) & $52 \mathrm{~mm}$ & $50 \mathrm{~mm}$ & $179 \mathrm{~mm}$ & $116 \mathrm{~mm}$ \\
Duration of rainfall event & $<24 \mathrm{~h}$ & $<24 \mathrm{~h}$ & $<24-96 \mathrm{~h}$ & $48-72 \mathrm{~h}$ \\
Seasonality & JAS & JJAS & JJAS & AS \\
Particle sizes $(\varnothing)$ & $<0.5 \mathrm{~m}$ & $0.5-1 \mathrm{~m}$ & $0.5-1 \mathrm{~m}$ & $1-2 \mathrm{~m}$ \\
Magnitude $\left(\mathrm{m}^{3}\right)$ & $10^{2}-10^{3}$ & $10^{3}-5 \times 10^{3}$ & $5 \times 10^{3}-10^{4}$ & $10^{4}-5 \times 10^{4}$ \\
\hline
\end{tabular}

Bold letters indicate peak in activity

$J J A S$ stands for June, July, August, and September 
4.4 Rainfall and debris-flow events: changes with time

Changes in seasonality in debris-flow activity are presented in Fig. 6, illustrating that events tend to occur always later in the season. The occurrence dates of events have shifted by almost 4 weeks since the late nineteenth century (i.e., from Julian day 207 to 234; mean: 223, max: 275, min: 151, SD: 29.8 days). This offset of activity from summer to late summer/early fall is also obvious when the incidence of debris flows is analyzed on a monthly scale and we observe a significant shift of events away from early June and July to August and September. This temporal shift in debris-flow occurrences becomes already obvious at the beginning of the last century, when warm-wet summers between 1916 and 1935 favored the release of debris flows later in the season and prevented early-season flows in June. As a result of

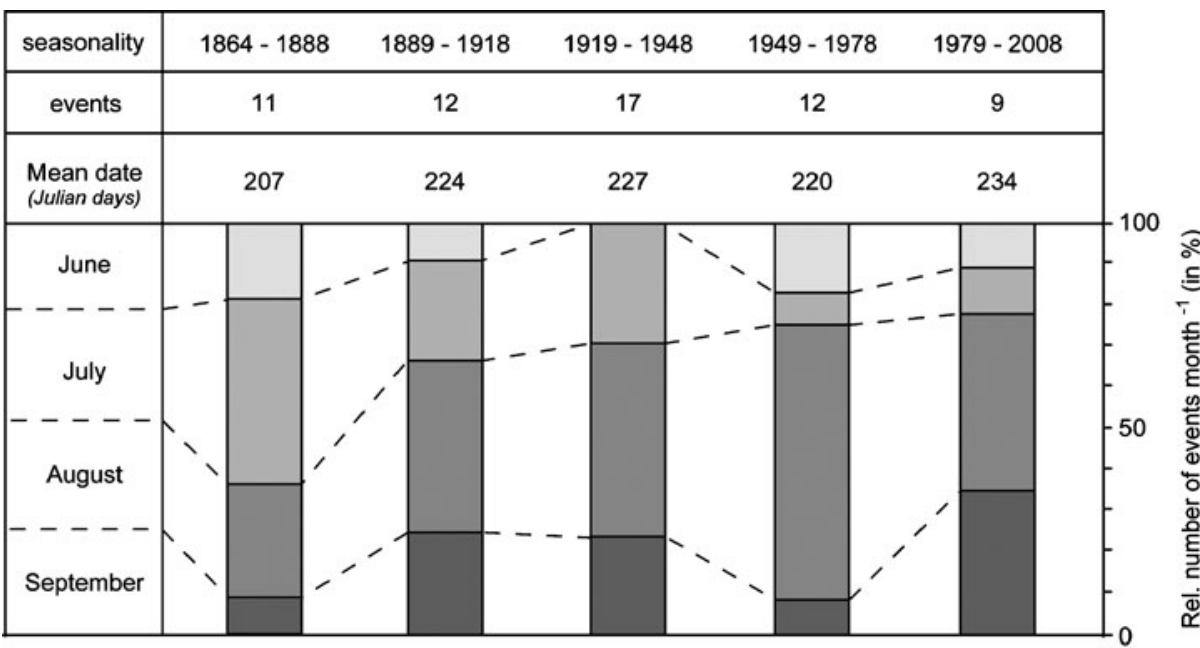

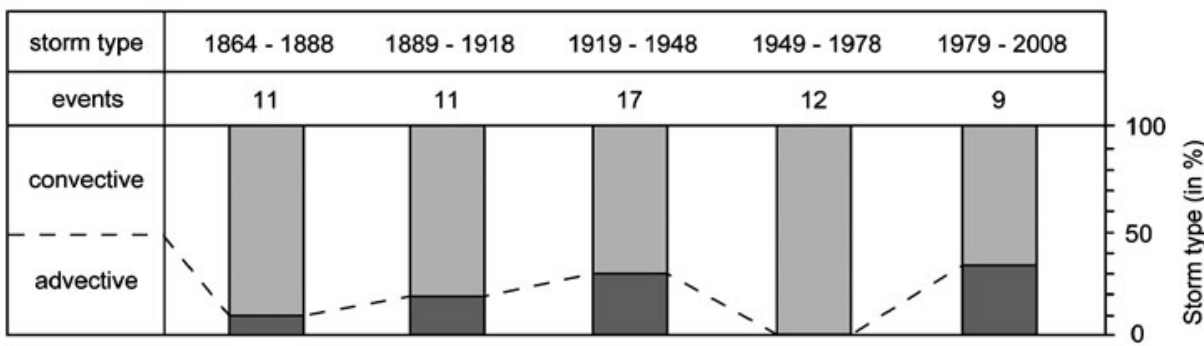

\begin{tabular}{|lccccc|}
\hline \multicolumn{5}{c|}{ precipitation totals recorded during convective / advective rainfall events (in mm) } \\
\hline mean & $30.9 / 48.7$ & $20.2 / 30.7$ & $20.9 / 66.7$ & $29.6 / \mathrm{NA}$ & $26.1 / 70.0$ \\
$\max$ & $49.3 / 48.7$ & $30.0 / 30.7$ & $30.2 / 179.4$ & $52.2 / \mathrm{NA}$ & $43.3 / 115.8$ \\
$\min$ & $16.5 / 48.7$ & $10.0 / 30.7$ & $19.0 / 35.1$ & $13.1 / \mathrm{NA}$ & $11.7 / 46.9$ \\
\hline
\end{tabular}

Fig. 6 Changes in seasonality of debris-flow events (top), storm types triggering debris flows (centre) and rainfall totals recorded during convective and advective storms with subsequent debris-flow releases (bottom) 
a temporal cooling tendency in the $1960 \mathrm{~s}$, occurrence dates dropped again to belowaverage values (AD 1949-1978). For the most recent past, data again indicates a very pronounced offset of occurrence dates with a mean value of 234 Julian days and a predominance of August and September debris flows.

In addition, results clearly exhibit a concentration of advective events with longlasting rainfalls in periods of warm-wet summers as was the case between 1916 and 1935 and towards the end of the last century, when an increase of $T_{\text {mean }}$ and $T_{\max }$ in combination with well-developed low-pressure systems over the Mediterranean favored large precipitation totals and high $0^{\circ}$ isoclines. Interestingly, advective events did not, apparently, trigger debris flows during the 1950s, 1960s and 1970s.

In addition, we observe changes in mean and maximum precipitation totals of all those convective and advective events that actually triggered debris flows. Although the changes observed between the different time windows are not statistically significant, they nonetheless indicate a temporal reduction of mean precipitation sums and lower maxima between the late 1880s and the mid twentieth century and an increase of rainfall totals during late-twentieth century advective events.

It also becomes obvious from Fig. 6 that the frequency of events in general and the incidence of large events did not increase as a result of the changes observed in $T_{\text {mean }}$ or $T_{\max }$. In contrast, it appears that debris flows are becoming less frequent in this high-elevation watershed.

\section{Discussion and conclusion}

This paper addresses relationships between rainfall inputs and mass-movement outputs in a high-elevation, permafrost-dominated watershed. In particular, it presents an analysis of rainfall records and tree-ring based debris-flow data for a catchment in the southern Swiss Alps covering almost 150 years.

The existence of highly resolved, tree-ring based debris-flow records and onsite meteorological measurements reaching back to A.D. 1864 is probably unique and forms an excellent basis for the analysis of triggers of past and interpretation of potential future mass movements. However, as the recording meteorological instruments are located $1.3 \mathrm{~km}$ away from and $950 \mathrm{~m}$ below the release zone of debris flows, it is possible that differences exist between measured and real spatial distribution and intensity of rainfall (Harremoës and Mikkelsen 1995). Buchanan et al. (1990), for instance, measured precipitation at their research site that were 1.9 times greater than those registered at the nearest recording rain gauge, which was, in their case, located $21 \mathrm{~km}$ from the study site. The spatial variation of precipitation is especially evident during convective storms, as these tend to be very localized and can develop in the upper reaches of catchments where debris flows are typically released (Van Steijn 1996), which in turn leads to a low-altitude bias in precipitation estimates for high-altitude watersheds (Dettinger and Diaz 2000).

At the recording meteorological station of Grächen, precipitation events exceeding $50 \mathrm{~mm} \mathrm{day}^{-1}$ (Fig. 3a) occur roughly 1 year in four, and this trend has not changed in the recent part of the record, as already shown by Beniston (2006) in his analysis of past and future heavy precipitation events for the entire Swiss Alps. While there are no trends visible in the frequency of heavy rainfall events, we observe a 
cluster of advective storms in late summer and early fall since the late 1980s. As a consequence, many of the debris flows of the past $25 \mathrm{yr}$ were triggered by advective rains and less frequently released during thunderstorms, which is in strong contrast to the 1950s, 1960s and 1970s when debris flows were released by convective storms. These changes in triggering meteorological conditions likely reflect the observed changes in extreme pressure systems and their persistence over the Alps. We speculate that the presence of more extreme and more persistent pressure systems and associated changes in the cool-dry and warm-dry modes are probably also responsible for the scarcity of debris flows and the unusually large return intervals in the Ritigraben torrent in the recent record. At a larger scale, we observe that these changes in cool-dry and warm-dry mode are consistent with the behavior of the North Atlantic Oscillation (NAO), where observational data illustrate that the NAO entered into a long period of positive (i.e. warm) modes from the 1970s to the late 1990s (e.g., Beniston and Jungo 2002), with significant associated temperature and precipitation anomalies during the positive phase of the NAO and related changes in the circulation patterns that affect the Alps.

Our tree-ring records also indicate the presence of (early-season) debris flows released by rainfalls of very moderate intensity, with as little as $10-12 \mathrm{~mm}$ being recorded at the gauge station at Grächen. These rainfall amounts are also well below the envelope proposed by Caine (1980), and only half the estimate of $25 \mathrm{~mm}$ during $1 \mathrm{~h}$, as reported by Van Steijn (1996) for debris flows $<100 \mathrm{~m}^{3}$. While the low intensities recorded may reflect partly some lag between the center of the storm cell and the rain gauge station, we realize that our observations of very moderate storms triggering debris flows are in concert with data from Spitsbergen (Rapp 1960; Larsson 1982), where comparably low thresholds have been reported. We believe that the oversaturation of the active layer of the permafrost body (i.e. impermeability of the ice) is responsible for the anomalously low rainfall intensities observed during earlyseason debris flows. For many of these events, data suggests that the antecedent rainfall regime may have exerted control on debris-flow initiation through the saturation of rock-glacier sediments with small grain sizes prior to small triggering rain storms and therefore agrees with different studies realized at lower-elevation sites (Campbell 1974; Moser and Hohensinn 1983; Cannon and Ellen 1985; Wieczorek 1987; Dick et al. 1997). The influence of snow melt seems to be, in contrast, less important and rain-on-snow as a trigger of debris flows-as suggested inter alia by Sharpe and Nobles (1953) or Rapp and Stromquist (1979)—was only observed in nine cases $(15 \%)$ at this high-elevation catchment.

As a result, although the present investigation is based on a comparably large set of rainfall and debris-flow data, setting any fixed rainfall threshold over which debris flows are generated at the study site does not seem feasible. First of all, changing responses of the debris-flow system to rainfall inputs clearly exist at different moments within the debris-flow season. These differences in system response reflect the control of the permafrost body on water infiltration, runoff, and sediment availability. Very small debris flows can therefore be released after very limited rainfall inputs (often $<20 \mathrm{~mm}$ ) in June and early July (see above). The same precipitation inputs will result in non-responses of the system in August or September, when a large active layer of the permafrost body will absorb larger water inputs without producing debris flows. In August and September, when meteorological conditions are more favorable 
for advective storms, excessive rainfall inputs (i.e. generally $>50 \mathrm{~mm}$ over 48-72 h) may lead to (partial) failures of the active layer of the permafrost body, yield massive amounts of sediment into the channel system and potentially trigger very large debris flows (Bovis and Jakob 1999; Lugon and Stoffel 2010). Another important reason for the absence of clear rainfall thresholds for the release of debris flows results from the coarse resolution of the daily timescale of rain gauge data and because most debris flows occur at unknown times during a storm, which increases the difficulty in precisely linking them to precipitation intensity and precipitation totals (Jakob 1996). A definition of rainfall thresholds is therefore very critical for high-elevation sites and potentially leads to spurious results and large deviations between predicted and observed values. Insufficient datasets are certainly an issue, but the existence of seasonally variable triggering parameters - sometimes other than climatic-are at least as important as rainfall inputs. We therefore agree with Pitlick (1994), who suggests that rainfall intensities are of prime importance for the generation of debris flows, but feel that large events can only be produced by an optimal combination of storm duration (rather than intensity!) and seasonal availability of debris in the source area of events in high-elevation watersheds.

With the projected climatic change, it is probable that changes will occur in the seasonality, return intervals and volumes of debris flows. Based on the tree-ring record, we observe a shift in debris-flow activity from June and July to August and September over the twentieth century as well as a concentration of advective rainstorms in late summer and early fall over the past $20 \mathrm{yr}$. Findings are in concert with data from Schmidli and Frei (2005), indicating a decrease in heavy summer rainfalls and a slightly positive trend in heavy fall precipitation intensities for the wider case-study region. Results from RCM runs based on the IPCC A2 greenhousegas emissions scenario (Beniston 2006) suggest a comparable shift in the occurrence of heavy precipitation events in the Swiss Alps from summer to spring and fall in a greenhouse climate by the end of the century. As spring and fall temperatures are projected to remain $2-5^{\circ} \mathrm{C}$ degrees below current summer temperatures-implying lower freezing levels in future springs and falls as compared with current summers, we could expect widespread buffering effects of snow on runoff and an absence of debris entrainment. At the same time, RCM model projections also suggest the probability of occurrence of intense advective rainfalls to increase in future falls (Stoffel and Beniston 2006). As a result of the suggested decrease in heavy summer rainfalls, it is conceivable that the overall frequency of events would reduce (Stoffel et al. 2008b), leaving more time for debris-flow material to accumulate in the channel (Lugon and Stoffel 2010).

As shown inter alia by Beniston (2004), rates of change in $T_{\max }$ in the Swiss Alps are far greater than the global-average warming of about $0.7^{\circ} \mathrm{C}$ per century (e.g., Jones and Moberg 2003), and seem to be a trend common to many other mountain regions of the world. While these changes in mean and extreme temperatures, and the increased persistence of extremely warm events in the most recent part of the record, do not in themselves explain occurrence or absence of debris flows at the Ritigraben study site, they may help identify the potential emergence of modified situations. Interactions between high temperature levels and their persistence, and the associated melting of interstitial ice or 'surging' of permafrost bodies on mountain slopes (Jackson et al. 1987; Harris et al. 2009) need to be closely monitored, as the destabilization of steep rock glaciers within the belt of permafrost may indeed result 
in instability of rock glaciers and delivery of large amounts of sediments into debrisflow channels (Lugon and Stoffel 2010), as is currently the case at several sites in the wider case-study region.

The combined effect of (1) presumably less frequent, yet more intense heavy rainfalls (Stoffel and Beniston 2006; Beniston et al. 2007), (2) increased sediment accumulation rates in channels (Lugon and Stoffel 2010) and (3) the destabilization of steep rock-glacier bodies (e.g., Kääb et al. 2007) will ultimately exert control on debris-flow volume (Stoffel 2010) released from the source area of debris flows. Extremely large debris flows, beyond historical experience and with volumes $>5 \times$ $10^{4} \mathrm{~m}^{3}$ are thus likely to occur at the case-study site in the nearer future. In a more distant future, complete wasting of permafrost in the rock-glacier body could, in contrast, lead to limitations in material supply into the debris-flow system and to a subsequent reduction in debris-flow frequency and magnitude.

Acknowledgements This work has been undertaken partly in the context of the EU-FP7 project $A C Q W A$ (GOCE-20290), the SFP-SRCE project RUFINE and the Era.Net Circle project ARNICA. Michelle Bollschweiler was supported by a post-doctoral grant from the AXA Research Fund. We are indebted to S. Widmer and A. Leutwiler for their help with the digitalization of hand-written meteorological data and to MeteoSwiss for granting us access to their archives. Comments by late Stephen H. Schneider, David R. Butler and Vincent Jomelli helped to improve a previous version of the manuscript.

\section{References}

Alestalo J (1971) Dendrochronological interpretation of geomorphic processes. Fennia 105:1-139

Allen MR, Ingram WJ (2002) Constraints on future changes in climate and the hydrologic cycle. Nature 419:224-232

Beniston M (2004) Extreme climatic events: examples from the Alpine region. J Phys IV 121:139149

Beniston M (2006) August 2005 intense rainfall event in Switzerland: not necessarily an analog for strong convective events in a greenhouse climate. Geophys Res Lett 33:L05701

Beniston M (2007) Entering into the "greenhouse century": recent record temperatures in Switzerland are comparable to the upper temperature quantiles in a greenhouse climate. Geophys Res Lett 34:L16710

Beniston M (2009) Trends in joint quantiles of temperature and precipitation in Europe since 1901 and projected for 2100. Geophys Res Lett 36:L07707

Beniston M, Goyette S (2007) Changes in variability and persistence of climate in Switzerland: exploring 20th century observations and 21st century simulations. Glob Planet Change 57:1-15

Beniston M, Jungo P (2002) Shifts in the distributions of pressure, temperature and moisture in the alpine region in response to the behavior of the North Atlantic Oscillation. Theor Appl Climatol 71:29-42

Beniston M, Stephenson DB, Christensen OB, Ferro CAT, Frei C, Goyette S, Halsnaes K, Holt T, Jylhü K, Koffi B, Palutikoff J, Schöll R, Semmler T, Woth K (2007) Future extreme events in European climate; an exploration of Regional Climate Model projections. Clim Change 81:71-95

Bollschweiler M, Stoffel M (2010a) Changes and trends in debris-flow frequency since AD 1850: results from the Swiss Alps. The Holocene 20:907-916

Bollschweiler M, Stoffel M (2010b) Variations in debris-flow occurrence in an Alpine catchment-a reconstruction based on tree rings. Glob Planet Change 73:186-192

Bollschweiler M, Stoffel M, Schneuwly D (2008a) Dynamics in debris-flow activity on a forested cone-a case study using different dendroecological approaches. Catena 72(1):67-78

Bollschweiler M, Stoffel M, Schneuwly DM, Bourqui K (2008b) Traumatic resin ducts in Larix decidua trees impacted by debris flows. Tree Physiol 28:255-263 
Bovis MJ, Jakob M (1999) The role of debris supply conditions in predicting debris flow activity. Earth Surf Process Landf 24:1039-1054

Braam RR, Weiss EEJ, Burrough PA (1987) Spatial and temporal analysis of mass movement using dendrochronology. Catena 14:573-584

Buchanan P, Savigny KW, De Vries J (1990) Method for modeling water tables at debris avalanche headscarps. J Hydrol 113:61-88

Caine N (1980) The rainfall intensity-duration control of shallow landslides and debris flows. Geogr Ann 62A:23-27

Campbell RH (1974) Debris flows originating from soil slip during rainstorms in southern California. Q J Eng Geol London 7:339-349

Cannon SH, Ellen SD (1985) Rainfall conditions for abundant debris avalanches, San Francisco Bay region, California. Calif Geol 38:267-272

Cook ER, Kairiukstis LA (1990) Methods of dendrochronology—applications in the environmental sciences. Kluwer, London

Crozier MJ (1999) Prediction of rainfall-triggered landslides: a test of the antecedent water status model. Earth Surf Process Landf 24:825-833

Dettinger MD, Diaz HF (2000) Global characteristics of stream flow: seasonality and variability. J Hydrometeorol 1:289-310

Dick G, Anderson RS, Sampson DE (1997) Controls of flash flood magnitude and hydrograph shape, Upper Blue Hills badlands, Utah. Geology 25:45-48

Evans GE, Clague JJ (1994) Recent climatic change and catastrophic geomorphic processes in mountain environments. Geomorphology 10:107-128

Fantucci R, Sorriso-Valvo M (1999) Dendrogeomorphological analysis of a slope near Lago, Calabria (Italy). Geomorphology 30:165-174

Godt JW, Baum RL, Chleborad AF (2006) Rainfall characteristics for shallow landsliding in Seattle, Washington, USA. Earth Surf Process Landf 31:97-110

Goudie AS (2006) Global warming and fluvial geomorphology. Geomorphology 79:384-394

Grebner D, Roesch T (1998) Flächen-Mengen-Dauer-Beziehungen von Starkniederschlägen und mögliche Niederschlagsgrenzwerte im Raum der Schweiz, vdf Hochschulverlag AG, Zurich

Grove JM (2004) Little ice ages: ancient and modern. Routledge, London

Guzzetti F, Peruccacci S, Rossi M, Stark CP (2008) The rainfall intensity-duration control of shallow landslides and debris flows: an update. Landslides 5:3-17

Harremoës P, Mikkelsen PS (1995) Properties of extreme point rainfall. I. Results from a rain gauge system in Denmark. Atmos Res 37:277-286

Harris C, Arenson LU, Christiansen HH, Etzelmüller B, Frauenfelder R, Gruber S, Haeberli W, Hauck C, Hölzle M, Humlum O, Isaksen K, Kääb A, Kern-Lütschg MA, Lehning M, Matsuoka N, Murton JB, Nötzli J, Phillips M, Ross N, Seppälä M, Springman SM, Vonder Mühll D (2009) Permafrost and climate in Europe: monitoring and modelling thermal, geomorphological and geotechnical responses. Earth-sci Rev 92:117-171

Hupp CR (1984) Geo-botanical evidence of late Quaternary mass wasting in block field areas of Virginia. Earth Surf Process Landf 8:439-450

IPCCKostaschuck RA, MacDonald GM (Intergovernmental Panel on Climate Change) (2007) Climate change 2007-the physical science basis. Cambridge University Press, Cambridge

Jackson LE, Kostaschuck RA, MacDonald GM (1987) Identification of debris flow hazard on alluvial fans in the Canadian Rocky Mountains. Rev Eng Geol 7:115-124

Jakob M (1996) Morphometric and geotechnical controls of debris flow frequency and magnitude in southwestern British Columbia. Ph.D. dissertation. University of British Columbia, Vancouver, $\mathrm{p} 232$

Jomelli V, Pech VP, Chochillon C, Brunstein D (2004) Geomorphic variations of debris flows and recent climatic change in the French Alps. Clim Change 64:77-102

Jomelli V, Brunstein D, Grancher D, Pech P (2007) Is the response of hill slope debris flows to recent climate change univocal? A case study in the Massif des Ecrins (French Alps). Clim Change 85:119-137

Jomelli V, Brunstein D, Déqué M, Vrac M, Grancher D (2009) Impacts of future climatic change (2070-2099) on the potential occurrence of debris flows: a case study in the Massif des Ecrins (French Alps). Clim Change 97:171-191

Jones PD, Moberg A (2003) Hemispheric and large-scale surface air temperature variations: an extensive revision and an update to 2001. J Clim 16:206-223

Kääb A, Frauenfelder R, Roer I (2007) On the response of rock glacier creep to surface temperature increase. Glob Planet Change 56:172-187 
Larsson S (1982) Geomorphological effects on the Slopes of Longyear Valley, Spitsbergen, after a Heavy Rainstorm in July 1972. Geogr Ann 64A:105-125

Lugon R, Stoffel M (2010) Rock-glacier dynamics and magnitude-frequency relations of debris flows in a high-elevation watershed: Ritigraben, Swiss Alps. Glob Planet Change 73:202-210

Lütschg-Lötscher O (1926) Über Niederschlag und Abfluss im Hochgebirge: Sonderdarstellung des Mattmarkgebietes: ein Beitrag zur Fluss- und Gletscherkunde der Schweiz. Schweiz. Wasserwirtschaftsverband, Zürich

Mayer B, Stoffel M, Bollschweiler M, Rudolf-Miklau F, Hübl J (2010) Frequency and spread of hyperconcentrated flows on fans: a dendrogeomorphic case-study from a dolomite catchment in the Austrian Alps extending back to AD 1800. Geomorphology 118:199-206

McAuliffe JR, Scuderi LA, McFadden LD (2006) Tree-ring record of hillslope erosion and valley floor dynamics: landscape responses to climate variation during the last $400 \mathrm{yr}$ in the Colorado Plateau, northeastern Arizona. Glob Planet Change 50:184-201

MeteoSwiss (2009) Swiss Meteorological Office, www.meteoschweiz.ch (site last visited May 13, 2009)

Milly PCD, Weatherald TT, Dunne KA, Delworth TL (2002) Increasing risk of great floods in a changing climate. Nature 415:514-517

Moser M, Hohensinn F (1983) Geotechnical aspects of soil slips in Alpine regions. Eng Geol 19:185211

Pitlick J (1994) Relation between peak flow, precipitation, and physiography for five mountainous regions of Western USA. J Hydrol 53:219-240

Rapp A (1960) Recent development of mountain slopes in Kärkevagge and surroundings, northern Scandinavia. Geogr Ann 42:65-200

Rapp A, Stromquist L (1979) Field experiments on mass movements in the Scandinavian mountains with special reference to Kärkevagge, Swedish Lappland. Stud Geomorphol Carpatho- Balc 13:23-38

Rebetez M, Lugon R, Baeriswyl PA (1997) Climatic change and debris flows in high mountain regions: the case study of the Ritigraben torrent (Swiss Alps). Clim Change 36:371-389

Röthlisberger G (1991) Chronik der Unwetterschäden in der Schweiz. Ber Forschungsanstalt WSL $330: 1-122$

Schmidli J, Frei C (2005) Trends of heavy precipitation and wet and dry spells in Switzerland during the 20th century. Int J Climatol 25:753-771

Schneuwly DM, Stoffel M, Bollschweiler M (2009a) Formation and spread of callus tissue and tangential rows of resin ducts in Larix decidua and Picea abies following rockfall impacts. Tree Physiol 29:281-289

Schneuwly DM, Stoffel M, Dorren LKA, Berger F (2009b) Three-dimensional analysis of the anatomical growth response of European conifers to mechanical disturbance. Tree Physiol 29:1247-1257

Sharpe RP, Nobles LH (1953) Mudflow of 1941 at Wrightwood, southern California. Bull Geol Soc Am 64:547-560

Stoffel M (2008) Dating past geomorphic processes with tangential rows of traumatic resin ducts. Dendrochronologia 26:53-60

Stoffel M (2010) Magnitude-frequency relationships of debris flows-a case study based on field surveys and tree-ring records. Geomorphology 116:67-76

Stoffel M, Beniston M (2006) On the incidence of debris flows from the early little ice age to a future greenhouse climate: a case study from the Swiss Alps. Geophys Res Lett 33:L16404

Stoffel M, Bollschweiler M (2008) Tree-ring analysis in natural hazards research—an overview. Nat Hazards Earth Syst Sci 8:187-202

Stoffel M, Bollschweiler M (2009) What tree rings can tell about earth-surface processes. Teaching the principles of dendrogeomorphology. Geogr Compass 3:1013-1037

Stoffel M, Hitz OM (2008) Snow avalanche and rockfall impacts leave different anatomical signatures in tree rings of Larix decidua. Tree Physiol 28:1713-1720

Stoffel M, Lièvre I, Conus D, Grichting MA, Raetzo H, Gärtner HW, Monbaron M (2005a) 400 years of debris flow activity and triggering weather conditions: Ritigraben, Valais, Switzerland. Arct Antarc Alp Res 37:387-395

Stoffel M, Lièvre I, Monbaron M, Perret S (2005b) Seasonal timing of rockfall activity on a forested slope at Täschgufer (Valais, Swiss Alps) - a dendrochronological approach. Z Geomorphol 49:89-106

Stoffel M, Bollschweiler M, Hassler GR (2006) Differentiating events on a cone influenced by debrisflow and snow avalanche activity-a dendrogeomorphological approach. Earth Surf Process Landf 31:1424-1437 
Stoffel M, Bollschweiler M, Leutwiler A, Aeby P (2008a) Large debris-flow events and overbank sedimentation in the Illgraben torrent (Valais Alps, Switzerland). Open Geol J 2:18-29

Stoffel M, Conus D, Grichting MA, Lièvre I, Maître G (2008b) Unraveling the patterns of late Holocene debris-flow activity on a cone in the Swiss Alps: chronology, environment and implications for the future. Glob Planet Change 60:222-234

Stoffel M, Bollschweiler M, Butler DR, Luckman BH (2010) Tree rings and natural hazards: a stateof-the-art. Springer, Berlin

Tebaldi C, Hayhoe K, Arblaster JM, Meehl GA (2006) Going to the extremes: an intercomparison of model-simulated historical and future changes in extreme events. Clim Change 79:185-211

Van Steijn H (1996) Debris-flow magnitude-frequency relationships for mountainous regions of central and northwest Europe. Geomorphology 15:259-273

Wentz FJ, Ricciardulli L, Hilburn K, Mears C (2007) How much more rain will global warming bring? Science 317:233-235

Wieczorek GF (1987) Effect of rainfall intensity and duration on debris flows in central Santa Cruz Mountains, California. Rev Eng Geol 7:93-104

Zimmermann M, Mani P, Romang H (1997) Magnitude-frequency aspects of alpine debris flows. Eclogae Geol Helv 90:415-420 